\title{
SEENED TOIDULAUAL Suhtumine seenesöömisse ning selle dünaamika
}

\author{
Aivar JÜRGENSON
}

Ajaloo Instituut, Rüütli 6, 10130 Tallinn, Eesti; aivar20@mail.ee

Käesolevas artiklis antakse ülevaade seentesse suhtumisest ning seente tarvitamisest Euroopas ja Eestis. Näidatakse, millised muutused on selles vallas aset leidnud.

\section{MÜKOFIILSEST JA MÜKOFOOBSEST SUHTUMISEST}

Korjemajandus on varasemates kultuuriastmetes mänginud kahtlemata suuremat rolli kui hilisemates. Viljelevale majandusele üleminek tähendas muude muutuste kõrval pööret ka toidumajanduses - toiduvalmistamiseks vajaminev saadi põllult või karjast, mitte enam metsast või rabast. Muidugi on ka 20. sajandil metsikult kasvavaid taimi tarvitatud, eriti ikalduste või sõdade ajal, mil toiduga kitsas käes. Siis pole ära põlatud nõgese- või oblikasuppi ning seenedmarjadki on rohkem kasutamist leidnud. Kuid see pole ammu enam peamine toitumisviis.

Samas on tänapäevalgi maailmas rahvaid, kelle toidusedelisse kuuluvad seened ühe olulisima artiklina - seda eelkõige seente kõrge valgusisalduse tõttu. Tulemaalastel näiteks moodustavad seened vegetaarsest toidust peaosa. Sama on kirjutatud Kesk-Tšiilis elavate araukaanide kohta. Austraalia pärismaalaste hindavat suhtumist seentesse näitab nimetus metsameheleib. Seened on ilmselt üks varasemaid inimkonna toiduaineid. Seeni süüakse toorelt, kuivatatult või mõnel muul menetlusel töödeldult. Mõned mürgised liigid vabastatakse mürkainetest keetmise või kuuma tuha sisse matmisega, nagu teevad näiteks maoorid. ${ }^{1}$ Eestist on dokumenteeritud mitmeid arhailisi seente valmistamisviise, mis võiksid ehk olla hiliseks kajastuseks korjemajanduslikust staadiumist. Seeni on küpsetatud sütel $^{2}$ või lõkketulel. ${ }^{3}$

1 Hirschberg, W. (koost). Neues Wörterbuch der Völkerkunde. Berlin, 1988, 367; Forde, C. D. Habitat, Economy and Society. London, 1970, 98.

2 KV 50, $359<$ V.-Maarja (1939).

${ }^{3}$ KV 50, $861<$ Ridala (1939). 
Ühe teate järgi küpsetati lepatatikat raudvarda otsas pliidi all. ${ }^{4}$ Ka kevadel kasvavat mürklit on sel viisil valmistatud. Mürkel kasteti silgusoolvette, pisteti orgi otsa ja küpsetati sütetulel või ahjus. ${ }^{5}$ Mürgita pilvikuid on söödud toorelt. ${ }^{6}$ Siiski pole seente toorelt valmistamine eestlaste hulgas eriti levinud - need üksikud teadaolevad näited ei kajasta eestlaste seenetarbimises kindlasti mingeid üldisemat laadi trende.

Esimene, kes hakkas süstemaatiliselt uurima seente rolli inimkultuuris, oli R. Gordon Wasson. Muuhulgas tegi ta tähelepaneku, millele on oma hilisemates töödes toetunud mitmed seeni inimkultuuris uurinud autorid. Nimelt märkas ta erinevatel indoeuroopa rahvastel diametraalselt erinevat suhtumist seentesse. Kuigi seened kasvavad Euroopas igal maal, suhtuvad ühed rahvad neisse austusega, teised põlgusega. Wasson leidis, et seentesse eriilmelise suhtumise juured peituvad aegade hämaruses. ${ }^{7}$ Ta nimetas seenelembeseid rahvaid mükofiilseteks ja seeni põlgavaid mükofoobseteks. ${ }^{8}$ Erinevates kontekstides on täheldatud asjaolu, et kui näiteks slaavi ja romaani rahvad suhtuvad seentesse lugupidamisega ning tarvitavad seeni toiduks rohkesti, siis germaani rahvad on tuntud oma seenepõlguse poolest. On märgatud erinevat suhtumist seentesse ühelt poolt Idaja Kagu-Euroopas, teiselt poolt Lääne- ja Põhja-Euroopas. Nii näiteks jagab V. N. Toporov samuti mõtet kultuuride jagunemisest mükofiilseteks ja mükofoobseteks, kuid seda mastaapsemalt kui Wasson - samad tendentsid ilmnevad ka Euroopa-välises ruumis: esimestes tuntakse seeni hästi, teistes kesiselt. Vanad kreeklased nimetasid seeni jumalate toiduks, asteegid jumalate lihaks, mükofoobsed rahvad pidasid aga seeni saatana leivaks, surnute toiduks, väljaheiteks, st millekski, mis inimestele toiduks ei kõlba. ${ }^{9}$

Ka ühe kultuuri piires võivad arvamused seente kohta olla küllaltki vastukäivad. Saksa keeleruumis, mis kuulub kahe areaali kontaktalasse, on näiteks seeni söödud valdavalt vaid piirkondades, kus puututi kokku slaavi või romaani rahvastega. Preisimaal, kus oldi kontaktis slaavlastega, on sakslased hakanud varakult seeni korjama ja toiduks tarvitama. Innovatsioon võis stabiliseeruda ka seetõttu, et kuni 19. sajandini valitses seal krooniline toidunappus. ${ }^{10}$ Suhtumist

KV 318, $118<$ Jüri - E. Leek (1977).

5 ERA II 260, 49 (7) < Märjamaa - E. Poom (1939).

6 Vilbaste, G. i.a. Mürgiseid seeni ja seenemürgitusi. Käsikiri Eesti Kirjandusmuuseumi kultuuriloolises arhiivis. Fond 152, M 80: 4, lk 6.

7 Wasson, R. G. Soma: Divine Mushroom of Immortality. New York, 1968.

8 Wassonist ja tema teaduslikust pärandist avaldas käesoleva artikli autor Wassoni 100. sünniaastapäeva puhul 1998. aastal artikli Jürgenson, A. Suur seeneprohvet. Sada aastat etnomükoloogia rajaja R. Gordon Wassoni sünnist. - Akadeemia nr 12, 1998, 2604-2624. On analüüsitud tema rolli etnomükoloogia alusepanijana, tema hallutsinogeenseid seeni tutvustavat rolli ja mõju droogide subkultuuridele ning tema kohati vaieldavat panust etnoloogiateadusse.

9 Toporov, V. N. Gribõ. - Rmt: Mifõ narodov mira. Tom I. Moskva, 1987, 335.

10 Tolksdorf, Ulrich. Pilze als Nahrung. Zu Vorurteil und Innovation eines Nahrungsmittels in Norddeutschland. - Kieler Blätter zur Volkskunde nr 3, 1971, lk 7; Schürmann, Thomas. OstWest-Beziehungen in der Nahrungskultur. - Jahrbuch für deutsche und osteuropäische Volkskunde. Bd 37, Marburg, 1994, 146. 
kajastab näiteks seenenimetuste valik. Ida- ja Lääne-Preisimaa saksa keele murretes on ainuüksi kukeseene tähistamiseks 50 sünonüümi, Sileesias on punase kärbseseene tähistamiseks 11 sünonüümi. Mujal teatakse seenenimetusi hoopis vähem. ${ }^{11}$

Samamoodi kuulub kahe areaali kontaktalasse ka Eesti. Ühelt poolt skandinaavia ja saksa mõjud, teiselt poolt slaavi omad on kujundanud kultuuri, millel on ühisjooni mõlemalt poolt. Kui rääkida eesti talurahva suhtumisest seentesse, siis võib arhiivimaterjalidele toetudes täheldada seenekasutuses ilmnevat üldist tendentsi, et mida ida poole, seda rohkem on seeni söödud ning suhtuminegi seentesse on idas, st Peipsi ääres ja eriti Setumaal, lugupidavam kui mujal. A. Moora peab üheks seente korjamise põhjuseks Peipsimaal suuremate metsade olemasolu. ${ }^{12}$ See pole ilmselt siiski peamine. Kuna suured metsad laiuvad ka seenepõlglike elanikega piirkondades nagu Lääne-Eesti, siis on idaeestlaste seenekasutuses tõenäolisem siiski slaavi mõju. Seda tõendavad ka Ida-Eestis kasutatavad seenenimetused, mis on suures osas üle võetud venelastelt: padasinavik (подосиновик, haavapuravik, Leccinum aurantiacum), krasnuhha (краснуха, mitmed punased seened), valnuk (волнушка, kaseriisikas, Lactarius torminosus), maslänka (маслёнок, tatik (Suillus), puravik (Boletus)) jt. ${ }^{13}$

\section{SEENED ETNOTSENTRISMI INDIKAATORINA}

Valdkonnaks, milles ilmneb ühe või teise kultuuri suhtumine seentesse eriti selgelt, on kulinaaria. Kui kasutada kultuuriantropoloogia klassiku Claude LévyStraussi tuntud skeemi, siis kuuluvad seened mõneski kultuuris mitte-toidu (antifood) kategooriasse. Miks, see jääb paljudel juhtudel mõistatuseks. Üheks lähtekohaks võivad olla müütilised pärimused, mis teatavasti on sageli tabude aluseks. Tihti on seente toiduks keetmise vältimine seotud mõne kultuuriheerose algse ja väga olulise teoga, mis seostub loodusliku seisundi muutmisega kultuurseks. Seen jääb siis sümboliseerima kultuuristamata loodust. Paljudes mükofoobsetes kultuurides, näiteks eskimotel, on seened seotud just nimelt loodusega, st mittekultuursega, seen on toores, st mitte keedetud; mädanenud, st mitte kääritatud - ja muidugi välditakse teda siis ka toiduna. Mõnedes kultuurides identifitseeritakse

11 Tolksdorf, Ulrich. Pilze als Nahrung. Zu Vorurteil und Innovation eines Nahrungsmittels in Norddeutschland. - Kieler Blätter zur Volkskunde nr 3, 1971, lk 25; Sileesia seenetarvitamise kohta vt ka Staszczak, Zofia. Einige slavische Gemeinsamkeiten in der traditionellen Volkskultur Schlesiens anhand der Angaben des "Atlas der deutschen Volkskunde". - Ethnologia Slavica $\mathrm{nr}$ 4, 1972, $52 \mathrm{jj}$.

12 Moora, A. Eesti talurahva vanem toit II. Tallinn, 1991, 286.

13 Venepäraseid seenenimetusi kasutavad laialdaselt ka eestlastest väljarändajad Siberis, kusjuures ühe ja sama venekeelse sõnaga tähistatakse paikkonniti erinevaid bioloogilisi liike (autori välitööd 1996: Omski oblast). 
seeni kõdu ja põrmuga - jällegi on tegemist kultuuristatud maailma vastandiga. Kohati seostuvad seened ka heerose surnukehaga. Näiteks Tucuni müüdis hullust kütist (M240) või perekonnast, kes muudeti jaaguarideks (M304), esineb motiiv vanast naisest, kes tappis oma poja ja üritas ta maksa oma lapselastele sööta, öeldes, et tegemist on seenega. Seos seente ja põrmu vahel ilmneb lingvistilisel tasandil: prantsuse mousseron ${ }^{14}$ tähendab söödavat seent, moisi, moisissure tähendavad aga mulda, moisir - mullaga katma. Mõnedel Lõuna-Ameerika indiaanlastel seostuvad seened surma ja näljaga. Mõnes kultuuris on seened jumalate liha, ekskremendid vm eritised. ${ }^{15}$ Kui mõtleme siinkohal väljaheidete, sülje, oksendamise jne sümboolsele tähendusele mütoloogias, võime oletada, et ka eesti keeles kasutatav pejoratiivne sõna sitaseen kajastab ehk mingeid kaotsiläinud mütoloogilisi kujutelmi. Seen seisaks siis inimese ja jumala vahel ning tähistaks olulist märki teel loodusest kultuuri.

Seente välistamine toiduna, sh nende töötlemise - keetmine, küpsetamine jne - vältimine võib viidata olulisele tabude süsteemile arhailistes kultuurides. Näiteks havailaste juures tähendab juurviljade küpsetamine, et teha need inimesele vastuvõetavaks, ühtlasi nende jumalikkuse hävitamist - neilt võetakse neile toorest peast omane võime iseseisvalt paljuneda. ${ }^{16}$ Seente olulisus mütoloogilistes süsteemides ${ }^{17}$ võib olla põhjuseks, miks need triviaalsest toidusedelist välja lülitati, küll aga säilitasid seened koha sakraalsete vahendite hulgas.

Võib-olla sõid meie esivanemad seeni rohkem, kui meie seda teeme, kuid siinkohal peame piirduma vaid oletustega, sest tõendavaid andmeid napib. See pole üksnes meie probleem - seente kohta on säilinud kirjalikke vm allikaid vähevõitu ka teistel rahvastel. Me ei leia näiteks piiblist märke selle kohta, kas vanad heebrealased seeni sõid või mitte. Esimesed selged tõendid seente kohta pärinevad vanadelt kreeklastelt ja roomlastelt. Pompeist, mis mattus 79. aastal laava alla, avastati freskod, millel on kujutatud söögiseeni. ${ }^{18}$ Ka kirjalikud allikad tõendavad, et kreeklased ja roomlased seente suhtes ükskõiksed polnud. Martialis nimetas seeni väärtuslikuks toiduks (optimi cibi). ${ }^{19}$ Antiik-Roomast pärinevad ka esimesed seenetoitude retseptid. Nii annab roomlane Coelius Apicus retsepti trühvlite valmistamiseks: “...viiluta, keeda, raputa peale soola ja torka oks läbi; prae natuke ja pane keedunõusse vähese õliga, likööriga, maheda hõõgveiniga, segamata veiniga, pipra ja meega; kui keema läheb, sega peene jahuga; võta

14 Vanaprantsuse moisseron, mousheron, sellest tulenevad vanainglise muscheron, inglise mushroom.

Toporov, V. N. The Semiotics of Mythological Conceptions about Mushrooms. - Semiotica Vol. 53-4, 1985, 299-300, 329; Wasson, R. G., Kramrisch, S., Ott, J., Ruck, Carl A. P. Persephone's Quest: Entheogens and the Origins of Religion. New Haven and London, 1986, $30 \mathrm{jj}$.

16 Sahlins, M. Saared ajaloos. Tallinn, 2002, 127.

17 Vt Jürgenson, A. Kes külvab seeni? Pilguheit mükoloogia ja mütoloogia piirile. - Pro Folkloristica, 1999, 4, 55-69.

18 Moore-Landecker, E. Fundamentals of the Fungi. New Jersey, 1996, 2.

19 Heilborn, A. Unsere Pilze. Berlin, Leipzig, 1905, 24. 
oksad välja ja serveeri. ${ }^{20}$ Peab ütlema, et trühvlid olidki antiikmaailma hinnatuimad söögiseened. Mitte kõikidesse seentesse ei suhtutud sama lugupidavalt. Kivipuravikku näiteks nimetasid vanad roomlased seaseeneks (suillus), st millekski, mida peeti kõlbavaks vaid sigadele. Roomlastelt on see nimetus tõlkevastena jõudnud ka tänapäeva itaalia keelde (porcino). ${ }^{21} \mathrm{Ka}$ meie oma seariisikaga (tõmmuriisikas, Lactarius neccetor ${ }^{22}$ ) väljendame samasugust suhtumist. Sama lugu on lamba- või lehmatatiga. Veel sada aastat tagasi peeti Eesti saartel seeni kõlblikeks vaid lehmadele-lammastele. Taolised nimetused peegeldavad inimtoitumise kultuuriliselt selektiivset laadi. Samale semantikale nagu lambatatt või seaseen viitavad näiteks taimenimetused seaõied (võilill, Leontodon taraxacum), seahernes (Lathyrus) või seakapsas (seaohakas, Cirsium oleraceum), sealõuarohi (Leontodon), seapohl (leesikas), seatubakas (Helleborus), lambalääts (Trigonella), lambapähkel (Saxifraga granulata), kukeleib (Setaria), konnatatar (Polygonum convolvulvus) jne. Need on taimed, mida inimene söömiskõlblikuks üldjuhul ei tunnista või siis peetakse neid nii väheväärtuslikuks, et kõlbavad söögiks vaid loomadele.

Inimene peab iseenda maitset toidu väärtuslikkuse mõõdupuuks. See, mida sööb meie-grupp, on õige ja hea, see, mida keegi teine, aga mitte. Inimene ei erista end üksnes loomadest, vaid ka näiteks oma naabritest või mõnest tema jaoks eksootilise rahva esindajast. Selle järgi, mida keegi sööb, teeme tema kohta sageli järeldusi. Ikka on tegemist mingi nähtusega, mida meie oma sisseharjutatud kultuurimustri järgi peame kõrvalekaldeks või liialduseks. Algonkinid ütlesid oma naabrite innuitide kohta escimancik, mis tähendab toore liha sööjat. Meie saime sellest toitumisele viitavast näpuganäitamisest eskimo. Maiad kutsusid hispaanlasi anona-sööjateks (vili, mida nad ise toiduks ei tarvita). ${ }^{23}$ Taanlastele on silma hakanud, et sakslased söövad vorsti rohkem kui nemad, nimetades neid seepärast vorstisööjateks. Kogu Euroopa tunneb prantslasi konnasööjate nime all. Tuntud on beefeater priske inglase tähenduses. Venelased on läinud veel kaugemale ja nimetavad oma põhjanaabreid samojeedideks - iseenda- ehk siis inimsööjateks - ja nii tunneb neid nüüd kogu maailm, kuigi nad muidugi iseennast ei söö. Pangem tähele - kui viitame teiste rahvaste toitumisharjumustele, on need ikka pejoratiivsed määratlused. On see ju etnotsentrismi nurgakivi, et oma kultuurimustrisse kuuluv on hea ja õige, võoraste oma aga vale ja halb. Grupikesksele toidumajandusele on omased konservatiivsed maitse-eelistused, millest tuleneb, et mitte-meie ja mitte-toit kuuluvad kokku, võõrad tarvitavad söögiks kõlbmatuid asju.

20 Ka tänapäeval on trühvlid kõrgeimalt hinnatud seened. Prantsusmaal kogutakse neid väljaõpetatud koerte ja sigadega, kes leiavad need maa alt üles. Palju müüakse trühvleid Põhja-Aafrika ja Lähis-Ida turgudel (Moore-Landecker, E. Fundamentals of the Fungi. New Jersey, 1996, 541).

21 Heilborn, A. Unsere Pilze. Berlin, Leipzig, 1905, 24.

22 Vt Spuhl-Rotalia, J. G. Kodumaa seened. - Majapidaja hinnata kaasanne. Haapsalu, 1905, 31.

23 Todorov, T. Ameerika vallutamine. Teise probleem. Tallinn, 2001, 104. 
Sama skeem töötab ka seente puhul. Ilmari Mannise teatel ütlesid soomlased veel 20. sajandi algul seente kohta sammakon saarnastuoli. Mitmeid seeneliike põlati halvaks toiduks, mis kõlbavat vaid venelastele. ${ }^{24}$ Samasugune on olukord Eestis. Mitmeid muidu väärtuslikke seeneliike eestlased ei korja ning peavad neid kõlbavaks vaid venelastele. Lehmatatikat tuntakse kohati vene-tati nime all. ${ }^{25}$ On teisigi kriteeriume, mille järgi eestlased - ja isegi setud - eristavad iseendi seenetarvitamist venelaste omast. Näiteks väidavad eestlased, et venelased korjavad seeni koos ussidega, mida eestlased ei tee. ${ }^{26}$

Ka eestlastest väljarändajate külades Siberis võib märgata erinevusi eestlaste ja venelaste seenekultuuris. Üks Sajaanide eelmäestikus paikneva Motorski küla mees (sündinud 1932) rääkis: Me kõiki seenesi ei söö-eestlased. A venelased korjavad patrjääd neid, kõikisugust rämpsu. Me korjame võiseened ja kaseseened ja kukeseened. Ja veel on... haavaseened.

Naabruses paiknevas Karatusi külas elav naine (sündinud 1922) rääkis venelaste seenekultuurist: A venelased korjavad kõikesugust seena söövad. Jaa, nendel on kõiksugused. Pargivad kõiki. Mõni ka lõppeb maha. Meie rahvas ei söönud.

Ülem-Bulanka eesti külas elav naine (sündinud 1926): Sitaseened meil on. Nad kasvavad nigu... kuskil nigu aedapidi või kustotsast niimoodi. Meie neid ei söö. Venelased küll söövad. A meie ei söö neid.

Viimati tsiteeritud naise poeg, kes vestluse juures viibis, alustas erinevate seeneliikide kirjeldamist: Opjaata, masljaata... Eelkõneleja katkestab teda poolelt lauselt: Vot need ongi need sitaseened kõik, need korjavad... neid ljäpasi ja pljäpasi. A meie neid ei korja. Me pole neid toond-neid ljäpasi ja pljäpasi. Meie ei söö neid. Ainult võiseent sööme, kaseseent sööme, kukeseent sööme ja aavaseent.

Kui eeltsiteeritud Motorski küla mees kirjeldas seente soolamist, siis siingi ilmnevad erinevused venelastega võrreldes. Kui eestlased kupatavad seeni enne soolamist, siis venelased mitte: A venelased teevad teistmoodi, toorelt. Külma veega leotavad ära, pesevad ära ja siis soolavad. /.../ A minule nad ei meeldi niimoodi.

Saksamaal, kus seeni pole toiduna eriti hinnatud, pole siltide kleepimine selles vallas samuti tundmatu. U. Tolksdorfi andmetel muutusid mõnes Saksamaa piirkonnas pärast 1945. aastat, kui maale valgus hulgaliselt põgenikke endistelt nn Ida aladelt, terminid põgenik ja seeneline sünonüümideks. ${ }^{27} \mathrm{Ja}$ kui Friedrich Ratzeli klassikalises etnoloogiateoses ${ }^{28}$ on ära toodud Põhja-Ameerikas käibinud

24 Manninen, I. Überreste der Sammlerstufe und die Notnahrung aus dem Pflanzenreich bei den nordeurasischen, vorzugsweise den finnischen Völkern. Eurasia Septentionalis Antiqua VI, 1931, 47.

Itkonen, E., Joki, A. J. Suomen kielen etymologinen sanakirja IV. Helsinki, 1983, 1246.

27 104, 1066 < Jõhvi (1962); autori välitööd 1992: Setu, Vilo v, Laberitsa k

Tolksdorf, U. Pilze als Nahrung. Zu Vorurteil und Innovation eines Nahrungsmittels in Norddeutschland. - Kieler Blätter zur Volkskunde nr 3, 1971, 13.

28 Ratzel, F. Völkerkunde I. Leipzig, Wien, 1894, 452. 
termin indiaanlaseleib (tegemist on teatava, kuni 30 naela kaaluva seeneliigiga), siis pole raske aimata, millises kontekstis valged asunikud seda sõna kasutasid ning kuidas see kajastas nende suhtumist seentesse.

\section{SEENED EUROOPA TOITUMISMUSTRIS}

Seenesöömisse suhtumises valitsevad Euroopa mastaabis nii geograafilised kui ajaloolised erinevused. Meenutame indoeuroopa rahvaste jagamist mükofiilseteks ning mükofoobseteks. Samamoodi on ka ajalisel skaalal võimalik piire tõmmata. Keskaegne Euroopa oli seente suhtes tunduvalt tõrjuvam kui näiteks 19. või 20. sajandi oma. Kui veel kord kasutada C. Lévi-Straussi jaotust, siis kuulusid seened keskaja Euroopas üsna üheselt kategooriasse "mitte-toit". Enamgi veel, keskajal ja uusaja algul olid "seen" ja "surm" peaaegu sünonüümsed. ${ }^{29}$ Reserveeritud olid seente suhtes autorid, kes neid oma teostes mainisid, näiteks Albertus Magnus, Hildegard von Bingen, Konrad von Megenberg. Ometi oli kas või antiikautorite vahendusel teada, et paljud seened on söödavad. Nii kirjeldas J. H. Zedleri leksikon aastal 1733 vähemalt 31 heamaitselist seeneliiki. Samas jäi nimetatud teos seentesse suhtumises võrdlemisi ambivalentsele seisukohale. Raamatus soovitatakse seeni pigem karta kui end ohtu seada: "Kõige parem aga on, et seeni ja teisi ihu haigeks tegevaid toite täielikult välditaks, kui et ennast nende himustamisest või veel enam, pahast harjumusest, ohtu seatakse. /.../ Sest köökides võidakse valmistada just selliseid seeni, nagu tahetakse, ometi säilitavad nad [seened] endas roojasust ja peaaegu mürki, kuna nende algupäraks on kõiksugune maapinna, puude ja teiste kõdunenud asjade mustus, mäda ja limane niiskus, samuti puutuvad nad kokku madude, kärnkonnade ja ämblikega., 30

See tsitaat vahendab meile üleüldist arvamust, mis oli sajandeid Euroopas ringelnud, nimelt et seened saavad mürgi oma kasvukohast. Kuivõrd seente päritolu oli inimestele võrdlemisi hämar, ringlesid selle kohta erinevad hüpoteesid. Seente taksonoomiline jaotus, nii nagu see 18. sajandil tekkis, oli keskajal kindlasti tundmatu. Seente jagunemine söödavateks ja mürgisteks liikideks polnud keskajal eriti selgepiiriline. Piisas paari liigi mürgisusest, et tõugata kogu seeneriik inimeste teadvuses eluohtlikku sfääri. See võis olla üheks seente vähese toiduks tarvitamise põhjuseks. Teine - ja kindlasti mitte vähem oluline - põhjus oli keskaegse toitumismustri spetsiifika. Peamine, millele tähelepanu pöörati, oli toiduainete toiteväärtus, rammusus. Seetõttu hõivasid inimeste toidusedelis koha liha ja teravili, mitte aga puu- ja juurviljad vms roheline. Näiteks oli 1549. aastal Catharina di Medici auks Pariisi linna poolt antud pidusöögi menüüs 24 liiki liha,

29 Tolksdorf, U. Sammelnahrung in Ost- und Westpreussen. - Jahrbuch für ostdeutsche Volkskunde. Bd 16, 1973, 52; vt ka Schürmann, Th. Ost-West-Beziehungen in der Nahrungskultur. Jahrbuch für deutsche und osteuropäische Volkskunde. Bd 37, Marburg, 1994, 146.

30 Zedler, J. H. (koost). Grosses Vollständiges Universal-Lexikon Aller Wissenschaften und Künste, Bd 20. Halle, Leipzig, 1739, 1858. 
mitut sorti kooke ja küpsiseid ja ainult 4 juurviljarooga. ${ }^{31}$ Rootsi kuninga Gustav II Adolfi menüü näitab sama tendentsi ka veel sada aastat hiljem - köögivili puudub selles täiesti. ${ }^{32}$ Kahtlemata ei kajasta kõrgkihi toidulaud kõigi elanikkonna kihtide toitumismustrit, kindlasti ei söönud ka kõrgkiht igapäevaselt nii nagu esinduslikel pidudel, kuid teatud tendentse taolised menüüd ometi näitavad.

Ja kuivõrd toiduaineid hinnati eelkõige toiteväärtuse alusel, ei saanud taimetoit selles plaanis kõrgelt väärtustatud olla. Kui keskaegne inimene taimetoitu üldse kuidagi väärtustas, siis eelkõige selle tervislikkusest lähtudes. Igasugused juurikad ja rohelised viljad olid kasutuses pigem ravimina kui toiduna. Siin mainigem vaid, et pole teada, et seentel keskaegse Euroopa meditsiinis eriti märkimisväärset kohta oleks olnud. Ullrich Tolksdorfi meelest võis ka see soodustada seente lahterdamist kategooriasse "mitte-toit" ${ }^{33}$ Siinkohal tuleb aga täpsustada, et seened ei kuulunud keskaja inimese teadvuses tingimata taimetoidu hulka. Sellest allpool. Igatahes ei kajasta keskaegse Euroopa allikad seente toiduks tarvitamist peaaegu üldse. Sama võib öelda ka Eesti ala kohta. Kas see viitab tingimata sellele, et seeni üldse ei söödud, on iseasi. Sageli on just allikate puudumine selleks piirikiviks, mis otsustab meie teadmiste ulatuse. Arheoloogilistes leidudes ei saa seeni nende kiire kõdunemise tõttu esineda. Näiteks kui on analüüsitud Tartu 13.-14. sajandi jäätmeaukude sisu, on maapind päevavalgele toonud marjade ja puuviljade seemneid, - aga need säilivad paremini kui mõni pehme materjal. Proovides olid ülekaalus metsataimede seemned ja viljad, eriti söödavate metsamarjade (mustikas, sinikas, pohl, metsmaasikas, jõhvikas) seemned. ${ }^{34}$ Ka kirjalikud allikad veenavad, et keskaegne Eesti linnade toidulaud ei sisaldanud üksnes põllusaaduste produkte: metsloomad ja -linnud, pähklid ja ürdid viitavad püügimajanduse rollile toidulaua seadmisel. Tallinna ordumeistrite vastuvõtuks varutud toiduainete nimistus (1536. aasta) figureerivad muude kõrval ka marjad. ${ }^{35}$ Nii olid siis metsasaadused keskaegsetes linnades kasutuses. Kui arvestada sellega, et Saksa Ordu aladel koguti andamina ka seeni ${ }^{36}$, on selge, et neid ka tarvitati. Kuid samas: kuigi keskaegsetest kirjalikest arhiiviallikatest võib leida teateid näiteks kukeseente kohta $^{37}$, on need siiski võrdlemisi kidakeelsed. Keskaegsetes pidusöökide menüüdes esinevad kõikvõimalikud toiduained. Inna Põltsam toob oma monograafias ära pulmade, gildide peajootude, raehärrade pidusöömingute jne

31 Mennell, S. Söögiisu tsiviliseerumine. - Akadeemia nr 4, 1996, 792.

32 Valeri, Renèe. Mitteleuropäische Einflüsse auf die Nahrung in Schweden. - Nahrung und Tischkultur im Hanseraum (koost Günther Wiegelmann; Ruth-E. Mohrmann). Münster; New York, 1996, 331.

33 Tolksdorf, U. Pilze als Nahrung. Zu Vorurteil und Innovation eines Nahrungsmittels in Norddeutschland. - Kieler Blätter zur Volkskunde nr 3, 1971, 8.

34 Tammet, M. Tartu keskaegsete jäätmeaukude karpoloogilise analüüsi tulemusi. - Rmt: Loodusteaduslikke meetodeid Eesti arheoloogias (toim A.-M. Rõuk; J. Selirand). Tallinn, 1988, 101.

35 Põltsam, I. Söömine-joomine keskaegses Tallinnas. Tallinn, 2002, 96.

36 Tolksdorf, U. Sammelnahrung in Ost- und Westpreussen. - Jahrbuch für ostdeutsche Volkskunde. Bd 16, 1973, 40.

37 Vt Põltsam, I. Söömine-joomine keskaegses Tallinnas. Tallinn, 2002, 21. 
menüïd, - kuid üheski neist pole mainitud seeni. Isegi mitte paastuaegade pidumenüüs, kus esineb kõikvõimalikke kalaroogi, puuduvad seened. ${ }^{38}$ Samas kuulusid seened sümboolsel kujul omapärasel viisil ometi keskaja peene köögi juurde. Tollal oli tavaks toidu vormi muutmine, mille käigus anti pirukatele, magustoitudele jne taime- ja loomariigist pärit kuju. Linde, kalu jms järeleaimavate roogade kõrval esinesid ka seenekujulised. ${ }^{39}$

Arhiiviandmed ei kajasta olulisel määral seente tarvitamist kõrgkihi hulgas Eesti keskaegsetes linnades. Siiski oli veel üks sotsiaalne kategooria, kus seenetoitudel oli tõenäoliselt olulisem roll kui linna-aadli või kaupmeeste puhul. Selleks olid kloostrid ja nende elanikud. Keskajal olid seened Euroopas peamiselt munkade toit - need asendasid paastuaegadel liha. Alates Itaaliast moodustasid seened kloostrites juba varakult olulise osa toidust. ${ }^{40}$ Kindlasti ei saa kloostri köögi võimalikku mõju ka linnakodanike või isegi talurahva toidusedelile välistada. Igal juhul peame arvestama sellega, et difusioon linnast maale või saksa köögist eesti kööki on aset leidnud kindlasti juba alates keskajast - mõelgem siinkohal kas või alamsaksa köögimajandusega seotud terminitele, mis on ühel või teisel kujul eesti keelde jõudnud: frukost, glas, tallrik, gaffel, ämbar jne. Saksa keelest on eesti keelde jõudnud ametinimetused kokk, pagar; roanimetused supp, sült, kook, kakk, moos, sink, pekk jne, samuti sõnad köök, praadima. Ka mitmed seenenimetused on meile vahendatud saksa keelest. Saksalaenulised on mürkel, mürgel - Morchella, Gyromitra esculenta - ja sirmik - Lepiota.

Kui keskajal oli seente roll Euroopa kõrgkihi söögilaual marginaalne, siis järgnenud sajandid on toonud kaasa olulisi muudatusi. Eelkõige on need seotud üldiste struktuurimuutustega toidukultuuris ning sealtkaudu ka menüüs. Alates 15. sajandist muutusid üha olulisemaks toidu kvaliteet ning mitmekesisus. Kaubanduse laienemisega ning tänu selles aset leidnud tööjaotusele paranes toiduga varustamine. Murrang toiduvalmistamise alal leidis aset ilmselt Itaalia linnriikide õukondades, kust 16. ja 17. sajandi vahetusel kandus kulinaaria innovatiivsuse kese üle Prantsusmaale. Ilmusid uued rafineeritud toiduvalmistamise tehnikad, suurenes roogade sortiment. ${ }^{41}$ Sel ajal hakati üha rohkem ka seentega katsetama. Neid veeti mujale Euroopasse Itaaliast, Prantsusmaalt ja Venemaalt. Asjaolu, et

38 Vt Põltsam, I. Söömine-joomine keskaegses Tallinnas. Tallinn, 2002, 83 jj, 97, 106. Paastuda tuli kolmel päeval nädalas: kolmapäeval, reedel ja laupäeval; tähtsamate pühakute nimepäevade eel, kolm päeva igakordsete kvatembripäevade puhul ning kogu paastuaja jooksul peale pühapäevade. Vein, liha jt loomsed ained olid siis keelatud (Mennell, S. Söögiisu tsiviliseerumine. Akadeemia nr 4, 1996, 798).

39 Vt Põltsam, I. Söömine-joomine keskaegses Tallinnas. Tallinn, 2002, 74.

40 Marzell, H. Die Pflanzen im deutschen Volksleben. Jena, 1925, 28; Tolksdorf, U. Sammelnahrung in Ost- und Westpreussen. - Jahrbuch für ostdeutsche Volkskunde. Band 16, 1973. Mõne aja eest eesti keeles avaldatud kloostritoitude kogumikus sisaldub 33 rooga, neist kolm on spetsiaalsed seeneroad, kuid ka paljudes teistes toitudes on seened oluliseks komponendiks (vt Kard, P. 33 toitu kloostri moodi. Pärnu,1991).

41 Mennell, S. Söögiisu tsiviliseerumine. - Akadeemia nr 4, 1996, 804-805; Valeri, R. Mitteleuropäische Einflüsse auf die Nahrung in Schweden. - Nahrung und Tischkultur im Hanseraum (koost Günther Wiegelmann; Ruth-E. Mohrmann). Münster; New York, 1996, 325. 
seeni tuli tuua kaugelt ning need riknesid kergesti, muutis seened tõeliseks luksuskaubaks. Ka üksikud kodumaised seened leidsid vähesel määral tee aristokraatia söögilauale. Saksa keelealal tuntud termin Herrenpilze viitab just tollastele arengutele.

Euroopa söömiskultuur uuenes aga pidevalt. Sotsiaalne ülemkiht - aadel ja rikkad kaupmehed - kujundas Euroopa tarbimistrende. Toidulaua osas tähendas see eelkõige importkaupade kasutamist - kööki ilmusid vürtsid, lõunamaised puuviljad jne. Söögilaua uuenemise trendid lähtusid suuresti Prantsusmaalt. Laialt levinud arusaam, et "Prantsusmaal süüakse, mujal täidetakse kõhtu”, on oma juurtega just tolles ajas. Just Prantsusmaa õukonna söögilaud kujunes aristokraatia silmis mõõdupuuks, kuid tundus oma söömismudelitega ahvatlev ka teistele sotsiaalsetele kihtidele. Eelkõige peab siin rääkima noorest tõusvast kodanlusest, kes võttis paljudes eluvaldkondades eeskuju aadli käitumismustritest. Motiiviks oli siin prestiiž - taheti hakata sööma nii nagu aadel. ${ }^{42}$ On väidetud, et kui 18. sajandil tahtis kodanlus Prantsusmaa õukonna söömismudeleid järgida, puudus tal selleks enamikul juhtudel materiaalne ressurss ning see tõi kaasa gastronoomilised uuendused: jäljendamine leidis aset asendamise teel. ${ }^{43}$ Tegelikult olid needki arengud ajendatud mitte niivõrd materiaalsete vahendite nappusest ${ }^{44}$, kuivõrd eelkõige moest: selsamal eeskuju andval Prantsusmaal hakati näiteks 17. sajandil toite maitsestama imporditud vürtside asemel kodumaiste taimedega. Ja muuseas - vürtside kasutamises ei maksa ilmtingimata luksust näha: näiteks Rootsis polnud vürtsid juba 16. sajandil midagi iseäralikult eksklusiivset, sealse talupojagi köögis olid tuntud muskaat, kaneel jm. ${ }^{45}$

Rääkides seentest, hakati kalleid imporditavaid liike - Prantsusmaal näiteks kasvatati šampinjone juba 16. sajandil ning eksporditi intensiivselt - kodumaistega asendama. Kui vaesem elanikkond oli seentega ka varasematel sajanditel puudust leevendanud, siis nüüd muutusid seeneroad just kõrgkihtide poolt hinnatuna mitmekesisemaks. See puudutab muuseas paljusid teisigi korjemajanduse saadusi: metsaandidest said Euroopas, eriti 19. sajandil, delikatessid. Kui varem juurutas innovatsioone eelkõige aadel, siis nüüd rikastas toidulauda kodanlus ja seda eelkõige kodumaiste toodetega. Kasutusse jõudis nn sisemaine eksootika. ${ }^{46}$

42 Sellel on nähtud ka konkreetseid ajendeid poliitilisest ajaloost. Prantsuse revolutsiooni järel põgenesid aadlipered välismaale, nende kokad jäid töötuks ning hakkasid restorane asutama. Tulemuseks oli üleminek aadellikult seltsielult kodanlikule seltsielule, mis oli demokraatlikum, kuid samas tõusiklikum (Minaudier, J.-P. Milles seisneb rahva mälu? - Vikerkaar nr 10-11, 2003, 95).

43 Mennell, S. Söögiisu tsiviliseerumine. - Akadeemia nr 4, 1996, 807; Tolksdorf, U. Sammelnahrung in Ost- und Westpreussen. - Jahrbuch für ostdeutsche Volkskunde. Bd 16, 1973, 43.

44 On kirjutatud sellest, et Euroopa, sh Eesti linnakodanik, jõudis 18. sajandil oma elulaadilt aadlile üsna lähedale (vt Suurmaa, L. Tallinna saksa kaupmeeste varaloendites inventeeritud laua- ja kööginõud kultuuriajaloo allikana 18. sajandil. - Vana Tallinn XV (XIX) (koost Raimo Pullat), Tallinn, 2004, 31).

45 Valeri, R. Mitteleuropäische Einflüsse auf die Nahrung in Schweden. - Nahrung und Tischkultur im Hanseraum (koost Günther Wiegelmann; Ruth-E. Mohrmann). Münster; New York, 1996, 332.

46 Tolksdorf, U. Sammelnahrung in Ost- und Westpreussen. - Jahrbuch für ostdeutsche Volkskunde. Bd 16, 1973, 42, 53. 


\section{SEENED EESTLASE TOIDULAUAL}

Uued suunad jõudsid päris kiiresti ka Läänemere-äärsetesse maadesse. Ridamisi ilmuma hakanud eestikeelsed kokaraamatud näitavad, et trend, mis oli Lääne-Euroopas alguse saanud taotlusest kõrgkihte jäljendada, teisenes siinses miljöös tagasihoidlikuks sooviks pakkuda lihtsate vahenditega uuendusi eestlase kööki.

Esialgu olid eestikeelsed kokaraamatud mõeldud kokkadele, kes teenisid saksa isandate juures. Seetõttu arvab Ants Viires, et nende mõju eesti enda köögile ei saanud suur olla. ${ }^{47}$ Juba esimeses eesti keelde tõlgitud kokaraamatus $(1781)^{48}$ sisaldus kaks seeneretsepti: sissetehtud riisikad ning sissetehtud šampinjonid (sjampionid). ${ }^{49}$ Neis õpetatakse seeni kupatama ning soolama - õigupoolest ei midagi uut, sest nimetatud menetlused olid talurahva seas niigi tuntud. Maitsestamiseks soovitati pipart, loorberit, muskaati, - kuid needki polnud 18. sajandi lõpu Eestis enam haruldus.

Kokaraamatuid hakkas nüüdsest peale rohkem ilmuma. 1818. aastal avaldati Tallinnas raamatuke "Nou ja abbi, kui waesus ja nälg käe on", mille oli koostanud Saaremaa kirjamees J. W. L. v. Luce. Ta üritab kummutada eestlaste arvamust, et "söödavast rohust" kõhtu täis ei saa. Raamat juhatas sisse terve rea vastavasisulisi brošüure ning ajakirjanduses ilmunud artikleid - siitpeale oli sõnum eesti rahvale muutumatu terve järgnenud sajandi vältel: nälja peletamiseks söödagu metsasaadusi.

Nälg on eesti talurahvast saatnud läbi sajandite. Muinasjutud isekattuvast laudlinast või motiiv "ori taevas" kajastavad lihtrahva unistusi heast söömaajast. Rahvast toitumise osas harida püüdvad üllitised avaldasid teiste seas ka seenetoitude retsepte ja, nagu öeldud, oli üheks eesmärgiks pakkuda toidulaua katmiseks odavaid viise. "Talurahwa Köögi Raamat" aastast 1889 (lk 49) õpetab muuseas ka seeni toiduks valmistama, kusjuures pakutav on väga lihtne ja valmistatav käepärastest vahenditest. 1900. aastal ilmub Elise Auna "Kasuline Köögi ja Söögi raamat", mille üheks rubriigiks on "Lihtsad seeneroad"50 - siin õpetatakse seeni kupatama, praadima ning keetma, lisandiks vaid vürts, pipar, hapukoor ning sibul. Selliseid retsepte avaldati mitmes tollases kokaraamatus.

Lihtsate ja odavate toitude populariseerimine oli 20. sajandi algul levinud trend kogu Euroopas. Heaks näiteks tollaste ideede kohta on taani teadlase M. Hindhede "Eeskujulik kokaraamat. Tervislised, odavad ja maitsevad söögid. Täielik pööre meie toitumiseviisis", mis tõlkena ilmus Tallinnas 1911. aastal. "Need lapsed, kes

47 Viires, A. Kokaraamatud kultuuriloo kajastajatena. - Keel ja Kirjandus nr 3, 1985, 160.

48 Rootsis näiteks ilmus esimene kokaraamat aastal 1644 saksakeelsena. Selle koostajaks oli kuninganna Kristina kokk Dietrich Mein (Valeri, R. Mitteleuropäische Einflüsse auf die Nahrung in Schweden. - Nahrung und Tischkultur im Hanseraum (koost Günther Wiegelmann; Ruth-E. Mohrmann). Münster; New York, 1996, 326).

Aun, E. Kasuline Köögi ja Söögi raamat. A. Seidelberg: Tartu, 1900, 41-42. 
praegusel ajal Põhja-Amerika Ühisriikides sünnivad, saavad täiskasvanult veel neid päevi näha, kus inimesed oma nälja vaigistamiseks maapinna seest viimased juurikad välja kisuvad. /.../ Inimene ei hoia miskis muus asjas nii kangekaelselt vanadest kombetest kinni, kui just toiduasjas." ${ }^{51}$ Hindhede, kelle toitumislabori loomist ning teaduslikke eksperimente Taani valitsus 16000 krooniga aastas toetas, tõendas iseenda ja oma perekonna peal katsetades, et inimene saab palju odavama toiduga läbi, kui seni arvatud. Kuigi just seente puhul rõhutati tollal nende odavust ja kergesti kättesaadavust, sisaldab Hindhede raamat siiski vaid ühe seenetoidu retsepti - seened vasikapraega. ${ }^{52}$ Hinnad komponentide järel peavad loomulikult rõhutama asja odavust.

$1 \frac{1}{2}$ naela kartulaid -3 kop.

1 nael praejäänuseid -25 kop.

$1 \frac{1 / 4}{4}$ naela puravikke -15 kop.

4 loodi võid -4 kop.

Soola, pipart maitse järele.

$3 \frac{1}{2}$ loodi parmesani juustu - 4 kop.

Seentekeedu vett.

Kokku

51 kop.

\section{LIHAST TAIMEKS}

Eelkirjeldatu puudutab eelkõige üldisi trende läänelikus seeni puudutavas toidumajanduses. Kuivõrd Eesti ala on viimastel sajanditel olnud tugevasti mõjutatud just saksa kultuuriruumi arengutest, jõudsid mitmed uuendused siia võrdlemisi varakult.

Erinevalt kõrgkihtide söögisedelist, mida keskaegsed allikad kajastavad suhteliselt hästi, on info lihtrahva toidu kohta fragmentaarsem. Eriti selles osas, mis puudutab vähem kasutatavaid toiduaineid, sh seeni. Sellegipoolest teame näiteks tõsiasja, et erinevalt kõrgkihi toidulauast on seened paljudes Euroopa piirkondades olnud vaesema elanikkonna jaoks liha asendaja. Teaduskirjanduses on Euroopa kesk- ja uusaegse toidumajanduse puhul kasutatud jaotust, milles toiduained jagunevad toitvateks ning tervislikeks. Liha, kala ja teravili kuuluvad selles jaotuses toitva, juurviljad, marjad ja vürtsid tervisliku toidu kategooriasse. Liha aseainena kuulusid seened rubriiki "toitev" - see selgub muuseas toidukordade analüüsist. Kohati olid seened lihtrahva söögikordade süsteemis lõunasöögi oluline komponent. Liha asendajana ei käsitletud seeni taimetoiduna. Kui eespool oli juttu keskaegsest assotsiatsioonist seente ja surma vahel, siis hakkas see slaavi

51 Hindhede, M. Eeskujulik kokaraamat. Tervislised, odavad ja maitsevad söögid. Täielik pööre meie toitumiseviisis. Tallinn, 1911, 3.

52 Samas, 147. 
elanikkonna mõjul vähehaaval muutuma, seda eelkõige etnilistel kontaktaladel (näiteks Preisimaa) ja esmalt alamkihtide seas. ${ }^{53}$

Eestlaste seente toiduks tarvitamise kohta pärinevad esimesed üksikasjalikumad teated August Wilhelm Hupeli sulest. Erinevatest seeneliikidest kirjutades mainib ta, et siinne talurahvas ei pea lugu näiteks kaseriisikatest, tatikatest ega kukeseentest, et parimaks peetakse üht riisikat, mida talupoeg sööb soolakala asendajana. ${ }^{54}$ Kui mõtleme siin sellele, et eesti talurahva peamine leivakõrvane oli soolasilk ${ }^{55}$, siis on Hupeli märge vägagi tähenduslik. Ja kui näiteks Peipsi ääres nimetati tünni soolatud seent seenesilguks ${ }^{56}$, siis viitab ka see seente olulisusele toidumajanduses. Karksis öeldi: Räim ja siin pettäs` ütte`vääri pääl, ütte inna pääl $l^{57}$ - näeme, et seened aitasid Eesti erinevais paigus asendada vaesemale rahvale loomset toitu. Seentest keedeti suppi, neid lisati tangu- ja kartulipudrule. Tartu- ja Võrumaal söödi vastlapäevahommikul tavanditoiduna lihatükkidega tanguputru. Kui liha polnud, asendasid seda seened. ${ }^{58}$

Viljandimaal nimetati 19. sajandil seeni metshärjalihaks ja ühe jalaga oina ossiks, Võrumaal metskitselihaks või põdrapraeks ${ }^{59}$, Nõos metsasikalihaks ${ }^{60}$, Virumaal metsalihaks ${ }^{61}$, tuntud on ka väljend ühe jalaga linnu liha ${ }^{62}$ - seega annavad keeleandmed märkimisväärse ühemõttelisusega edasi seente positsiooni vaesema rahva söögisedelis.

Kui eelnevalt nägime, milliseid argumente kasutas ajakirjandus seente propageerimiseks, siis tasub siinkohal eraldi rõhutada, et press - nii eesti- kui saksakeelne - soovitas 19. sajandi lõpul ning 20. sajandi algul nappiva liha asendajana seeni ${ }^{63}$ - muster, mis kultuuris niigi juurdunud, sobis nimetatud kampaania osaks suurepäraselt. "Hulk sealiha ehk seeni mädaneb Saaremaa metsades tähelepanuta ära...," kirjutab Saarlane 1908. aastal. ${ }^{64}$ Võrdlus lihaga leidis näljaperioodidel kasutamist edaspidigi. Viimane taoline kampaania toimus veel II maailmasõja päevil,

53 Tolksdorf, U. Pilze als Nahrung. Zu Vorurteil und Innovation eines Nahrungsmittels in Norddeutschland. - Kieler Blätter zur Volkskunde nr 3, 1971, 18; Tolksdorf, U. Sammelnahrung in Ost- und Westpreussen. - Jahrbuch für ostdeutsche Volkskunde. Band 16, 1973, 52.

54 Hupel, A. W. Topographische Nachrichten von Lief- und Ehstland II. Riga, 1777, 505.

55 Vrd rootsi sillake-fish, soome silakka. Kala soolamine levis Läänemere piirkonnas 13. sajandil, millisest ajast võib ka pärineda nimetatud sõnatüvi. Ka Soome idamurdes tähistab silakka kodus soolatud kala (vt Talve, I. Suomen kansanomaisesta ruokataloudesta. Turun Yliopiston kansantieteen laitoksen toimituksia 2. Turku, 1973, 39).

56 Relve, H. Mürgiseened. - Eesti Loodus nr 8, 1982, 489; Relve, H. Seened-marjad rahva keeles ja meeles. - Horisont nr 5, 1995, 6. Peipsi ääres nimetati iga soolatud kala silguks - havisilk, ahvenasilk jne (Moora, A. Seened rahvatoidus. - Eesti Loodus nr 10, 1981, 649).

57 MS < Krk. - Taim (1937).

58 Moora, A. Seened rahvatoidus. - Eesti Loodus nr 10, 1981, 651.

59 EA 56, $105<$ Urvaste - E. Siil (1954).

60 Samas, 649.

61 KV 77, 32 (1947) - A. Krikmann.

62 Põdder, M. Mõni sõna söödavatest seentest. - Oma Maa nr 1, 1891, 41.

63 Nt Livländischer Hausfrauen-Kalender. IV Jahrgang. Riga, 1895, 49.

64 Saarlane 20.09.1908. 
kui ajakirjanduses üritati lugejaid veenda seente kõrges toiteväärtuses ning kasutati pealkirju nagu "Seened on head liha aseaineks". 65

Kui vaatame eestlaste rahvapäraseid seenetoitude retsepte, selgub, et enamik neist on struktuurilt pigem liha- kui taimetoidud. Seenekotlet ${ }^{66}$, tangupuder seentega $^{67}$, seenepirukas ${ }^{68}$ - kõikides neis retseptides paiknevad seened pigem liha kui taimetoidu lahtris.

Eesti Rahva Muuseumi arhiivimaterjalide põhjal koostatud eesti rahvapäraste toitude kogumikus sisalduvad järgmised seeneroad: seenesupp, seenesupp piimaga, kartuli-tangupuder seentega, seenepuder kartulitega, praetud suitsuribi seentega, hautatud puravikud või kukeseened, seenekaste, praetud seened munaga, seenesalat, seenesalat kohupiimaga. ${ }^{69}$

Sellele, et seent peeti talurahva seas pigem lihaks kui taimeks, viitab ka see, kuidas nimetatakse eesti keeles seene erinevaid osi. Me ei nimeta seene alumist osa mitte varreks, vaid jalaks. Nagu teatab A. Moora, nimetati puravike pealmist osa näiteks Nõos pekiks, Karksis lihaks. ${ }^{70}$

Seente ja liha paarisrakend ning seente väljalülitumine taimsest toidust ilmneb ka selles, milliseid sõnu kasutatakse toiduainete seisundi määratlemiseks. Kui marjad, puu- ja köögiviljad võivad olla kas toored või küpsed, siis seente, aga ka näiteks kala või liha puhul on vastavaks terminiks värske. Oluline on selles seoses ka toitumise situatsioon: kui taimetoitu söödi peamiselt kevadel - ühelt poolt tingisid seda fenoloogilised protsessid, teiselt poolt majanduslikud põhjused, siis seente - nagu ka liha - tarvitamise kõrgajaks on sügis ja talv. Mitmetel hilissuvistel või sügisestel kalendritähtpäevadel kuuluvad eestlaste tavanditoitude hulka seened: seenekaste jakobipäeval (25. juuli), erinevad seeneroad mihklipäeval (29. september), sügiseseks talgutoiduks on olnud seenesupp. ${ }^{71}$ Peipsimaal valmistati jõulu esimesel pühal seenepirukat. ${ }^{72}$ Tarvastust on vastlapäeva kohta teade, mille kohaselt keedeti vastlapäeval tanguputru seentega. ${ }^{73}$

Seente asendi määratlemisel liha- ja taimetoidu skaalal ei tohi tähelepanuta jätta ka toidukordade süsteemi. Seenetoidud - nagu ka lihatoidud - on traditsiooniliselt kuulunud lõunasesse menüüsse, samal ajal kui õhtuti söödi putrusid või suppe - hommikuks soojendati teadupärast eelmise päeva lõuna ülejääke.

Seente kuulumisele ühte kategooriasse lihatoiduga viitab ka nende valmistamisviis. Seeni säilitati nii nagu liha - kas värskes õhus kuivatatult või sissesoolatult. Seejuures toimus seente tünni soolamine praktiliselt samal viisil nagu liha soolaminegi.

65 Postimees nr 193 (17.09.), 1942: 4.

66 KV 104, 908 < Jõhvi - M. Kalm (1962).

67 EA 117, $146<$ Nõo - M. Paade (1957).

68 EA 117, 380 < Nõo - H. Keem (1957), seenesupp (EA 117, 146 < Nõo - M. Paade (1957)).

${ }^{69}$ Kalvik, S. Eesti rahvatoite. Tallinn, 1988, 117-119.

70 Vt Moora, A. Seened rahvatoidus. - Eesti Loodus nr 10, 1981, 650.

71 Kalvik, S. Pühade- ja tavanditoidud. Maalehe Raamat, i.a., 69, 77-78, 152.

72 KV 104, 908 < Jõhvi - M. Kalm (1962).

73 RKM II 142, 130 (2) < Tarvastu - E. Tampere. 
Kuni 19. sajandini oli seente peamiseks valmistamisviisiks - nii nagu ka lihal - keetmine. Lihapraadimist tuli sel ajal ka mujal Euroopas veel väga harva ette. ${ }^{74}$ Millal võis eesti kööki seentepraadimine jõuda, pole päriselt selge. A. Moora on pidanud seentepraadimist meil hiliseks nähtuseks, mis olevat tavaliseks muutunud alles 19/20. sajandi vahetuse paiku. ${ }^{75}$ Tegelikult on talurahvas seeni praadinud kindlasti juba 18. sajandil - selle kohta pärinevad teated A. W. Hupelilt. ${ }^{76}$ 20. sajandil on seenepraadimine aga olnud kindlasti levinuim seente valmistamise viis. Sajandivahetusel tulid suuresti kokanduskursuste ning kokaraamatute vahendusel kõikvõimalikud seenekotletid, šnitslid jne. Seejuures käsitatakse seeni nagu liha: need aetakse läbi hakklihamasina ning praetakse pannil koos sibulaga. Liha analoogiale viitavad ka karbonaadid: suuremad seened paneeritakse jahu või riivsaiaga ning praetakse või küpsetatakse.

Uus tendents, mis sai alguse 19. sajandi Euroopas ning jõudis sajandi lõpuks ka Baltimaile, pööras senise seenetoitude struktuuri pea peale. Kui seni olid seened olnud peamiselt vaesema elanikkonna toit ning nendega asendati liha, siis linnakodanluse poolt juurutatud toitumismustris, millest oli eespool juttu, pandi rõhku peentele seenesalatitele, marinaadidele jne. 1881. aastal ilmus Tartus Karl Treufeldti "Lühike õpetus söögide tegemisest ehk taluperenaese köögi-raamat", milles oli juttu ka seenesalatitest.

Peamiseks seenesalati valmistamise viisiks saab äädikalahuses marineerimine ning nii püsib see ka läbi 20. sajandi. Seente säilitamist äädikas tunti Euroopas juba vähemalt 16. sajandil. Rahvaliku arusaama järgi oli äädikalahuse kasutamisel ka see eelis, et nii sai teada, kas seen on söödav või mitte. Seened asetati äädikasse ja jälgiti, kas nad muutuvad pehmeks või mitte. Kui seened muutusid pehmeks, siis oli üldlevinud seisukoha järgi tegu söögiseenega. ${ }^{77}$ Marinaadiks on kasutatud lahjendatud ja magustatud äädikat ning maitseaineid: nelki, loorberilehti, sibulat, pipart, isegi kadakamarju on marinaadile lisatud. Seened keedeti nimetatud segus ning suleti võimalikult õhukindlalt klaasist või plekist anumatesse. Anuma sulgemiseks soovitati kasutada tammepuust kaant, mis oli pealt põiega kinni seotud. ${ }^{78}$ Ka plekktoosidesse konserveerimine sai Euroopas alguse tegelikult juba 19. sajandi algul, kui prantsuse kokk Appert selle innovatsiooniga lagedale tuli. Toosid joodeti pealt kinni ning seejärel keedeti koos sisuga. 19. sajandil olid plekktoosidesse tehtud konservid võrdlemisi kallis kaup, mida said endale lubada jõukamad inimesed. 19. sajandi lõpul vastav tehnika lihtsustus ning konservid muutusid kättesaadavaks ka teistele elanikkonna kihtidele. Sajandivahetusel muutus konservide valmistamine mõneski mõttes moenähtuseks - plekk-

74 Vt Tolksdorf, U. Sammelnahrung in Ost- und Westpreussen. - Jahrbuch für ostdeutsche Volkskunde. Bd 16, 1973, 60.

75 Moora, A. Seened rahvatoidus. - Eesti Loodus nr 10, 1981, 651.

76 Hupel, A. W. Topographische Nachrichten von Lief- und Ehstland II. Riga, 1777, 505.

77 Tolksdorf, U. Sammelnahrung in Ost- und Westpreussen. - Jahrbuch für ostdeutsche Volkskunde. Bd 16, 1973, 34.

78 Suur köögi sõber. Lihtsad, odawad, maitswad toidud. Tallinn, i.a., 75. 
toosidesse konserveeriti lisaks lihale ka köögivilja, sh uba, hernest, lillkapsast, porgandit, naerist. Ka eesti keeles ilmusid - peamiselt teistest keeltest tõlgituna konserveerimise õpetused. Teiste seas õpetati konserveerima ka seeni. Meie käsutuses olevate arhiiviandmete ${ }^{79}$ põhjal võib siiski väita, et vaatamata propagandale juurdus seente konserveerimine rahva seas võrdlemisi visalt, muutudes valdavaks alles 20. sajandi keskel ning kohati hiljemgi.

Kuivõrd seente puhul on tegemist kergesti rikneva toiduainega, on seenetoitude raamatutes pühendatud palju ruumi seente säilitamisele. Lisaks marineerimisele, mis on vähemalt Eesti alal suhteliselt hiline innovatsioon, õpetati neis raamatutes ka traditsioonilisi seente säilitamisviise - kuivatamist, soolamist ja hapendamist. Kui marineerimise puhul on eeskuju võetud peamiselt LääneEuroopast, siis traditsiooniliste säilitusviiside puhul pärinevad vastavad õpetused enamasti venekeelsest kirjandusest. Seente säilitamisviiside tutvustamine seeneretseptide raamatutes on olnud tavaline ka 20. sajandil.

Eelkirjeldatud arengud köögimajanduses olid esimesed märgid uuest tarbimiskäitumise trendist 19. sajandi lõpul - nimelt vegetaarlikust liikumisest ${ }^{80}$, mis sajandivahetusel üha jõudsamalt ka Eestis kanda kinnitas. Tegemist oli tõepoolest uue trendiga, kuigi taimetoitu on meil propageeritud ka varem - kui mõtleme kas või J. W. L. v. Luce eelmainitud raamatule aastast 1818. Luce motiiviks polnud siiski mitte tervisliku toidu tutvustamine, vaid eelkõige abinõudele viitamine, kuidas nälga leevendada. ${ }^{81} 19$. sajandi lõpul hakkasid aga ilmuma spetsiaalsed vegetaarlastele mõeldud kokaraamatud. Seni oli eesti talupoeg seeni söönud peamiselt vaid näljaaegadel, st korilusest ei kujunenud kestvat tarbimismustrit, - kui olud paranesid, kadus "näljatoit" söögilaualt ning naasti harjumuspärase toidu juurde. Nüüd aga sisendati eestlasele intensiivse propagandaga nii vastavasisulistes brošüurides kui ajakirjanduses, et seen ei pea olema tingimata näljatoit. Muudatus toitumissüsteemis oli oluline: seened ei assotsieerunud enam lihaga, vaid taimetoiduga ${ }^{82}$ Ja kuivõrd liha seostub toitvaga ning taimetoit tervislikuga ${ }^{83}$, on nihe märgatav ka selles plaanis. M. Sapas kirjutas 1911. aastal oma taimetoitudele keskenduvas kokaraamatus: "Taimetoitlus, inimesesoo esialgne toitluseviis, on uuemal ajal kõigis kulturamaades kui tähtjas küsimus jälle ärganud ja leiab palju poolehoidjaid, iseäranis nende seas, kes kadumaläinud tervist taga otsides taimetoitude

79 KV 77; KV 665; KV 666.

80 Kui 19. sajandi lõpul tabas Euroopa ühiskonna kõrgkihte hirm rasvumise ees, hakkasid kokakunsti uuendajad propageerima suunda lihtsamale, kergemale toidule (Mennell, S. Söögiisu tsiviliseerumine. - Akadeemia nr 4, 1996, 811).

81 J. W. L. von Luce kirjutas: "Et teie vägga pissut södavad rohhud tunnete, se on kül seks tunnistusseks, et Jummal wägga arwaste on lasknud nälga hädda teie peale tulla, muido olleksite kül hädda pärrast neid jubba õppinud tundma." (Luce, J. W. L. von. Nou ja abbi, kui waesus ja nälg käe on. Tallinn, 1818, 5.)

82 Vt Tolksdorf, U. Sammelnahrung in Ost- und Westpreussen. - Jahrbuch für ostdeutsche Volkskunde. Bd 16, 1973, 61.

83 Seenekaste on Lõuna-Eestis tuntud ka seeneravina (ERA II 269, 362 (12). Häädemeeste, Marta Mäesalu (1940)). 
hääst mõjust selle kohta teavad rääkida."84 "Perenaise leksikoni" seente peatüki sissejuhatav lause kõlab: "Koostiselt ja toiteväärtuselt seened sarnlevad aedviljadega. /.../ Liha nad ei või asendada." ${ }^{85}$ Kokaraamatutes ilmunud seeneretseptid esinevad enamasti samas peatükis taimetoiduga. Nii näiteks õpetatakse ühes keedukooliraamatus seenesuppi valmistama "Taimekeeduste" peatükis. ${ }^{86}$

Seeneroogade nihkumise puhul taimetoitude sekka oli tegemist välismaise innovatsiooniga. Kuid ka muus osas pakkusid 20. sajandi esimese poole kokaraamatud hulgaliselt uudseid ning meil senitundmatuid võtteid ning retsepte. Ilmusid sellised välismaised road nagu beefsteak, roastbeef, beef à la Stroganoff jne. Mida aeg edasi, seda enam diferentseerub ka seeneroogade valik. Ilmuvad sellised varem eestlasele tundmatud toidud nagu soojad võileivad - ja loomulikult katsetatakse siis neid katta muu seas ka seentega ${ }^{87}$ Kodumaiste seente kõrval hakatakse palju tarvitama eksporditavaid šampinjone. ${ }^{88}$ Torkab silma, et kui lihtsate kodumaiste seeneroogade puhul tehakse enamasti vahet ka liikidel - puravikud, riisikad vms -, siis võõrapärased või ka seeni vaid üksikkomponendina pakkuvad retseptid piirduvad märkusega seened. ${ }^{89}$ Mõnes kokaraamatus on vahet tehtud seentel ja šampinjonidel - ilmne märk sellest, et eksporditavad šampinjonid nõuavad kodumaiste seente kõrval eluruumi. Kahtlemata oli linnainimeste ja alates 20. sajandist üha rohkem ka maaelanike - köök orienteeritud turule. See tähendas, et üha rohkem toitu toodeti väljaspool kodu ning vastavalt sellele orienteerusid ka kokaraamatud eksportartiklitele. Samas jätkas ajakirjandus endiselt kodumaiste seeneliikide propageerimist. Tutvustatakse erinevaid puraviku- või riisikaliike ning võimalusi neist toite valmistada, sekka vahel ka mõnd vähem tuntud kübarseent, kuid üldiselt jääb seeneliikide valik piirduma siiski kümmekonna enam tuntud liigiga. Taoline sortimendi piiratus on olnud viimase sajandi jooksul iseloomulik ka Lääne-Euroopas tutvustatud seeneretseptidele. ${ }^{90}$

Kui varasemaga võrreldes muutus kokaraamatute seenetoitude valik 20. sajandi algupoolel "kergemaks" - oma koht oli kõikvõimalikel salatitel ning marinaadidel -, siis ei saa sellega ometi öelda, et varasemast ajast tuntud traditsioonilised road retseptivalikutest päriselt ära oleksid kadunud. Seesama "Perenaise leksikon" näiteks pakub seeni soolatult, salatina, käkkidena, vormina, kastmena, leemena jne. $^{91}$

${ }^{84}$ Sapas, M. Taimetoidud ja nende valmistamine. Tartu, 1911, 9.

85 Peters, E., Viburg, J., Geperson, E. Perenaise leksikon. Kodude teatmeraamat. Tallinn, 1933, 970.

86 Wäikene Keedukool. Söökide walmistamise õpetus keskmises majapidamises. Toimetanud keedukooli tegelased Tallinnas 1906. Tallinn, 1911, 72.

87 Vt Sild, E. Keedu- ja majapidamisraamat. Tartu, 1937, 175.

88 Samas, 182.

89 Nt Leesment-Mälberg, E. (toim). Perenaise käsiraamat. Tallinn, 1927.

90 Vt nt Tolksdorf, U. Pilze als Nahrung. Zu Vorurteil und Innovation eines Nahrungsmittels in Norddeutschland. - Kieler Blätter zur Volkskunde nr 3, 1971, 9.

91 Peters, E., Viburg, J., Geperson, E. Perenaise leksikon. Kodude teatmeraamat. Tallinn, 1933, 970. 
Kui 19. sajandi lõpuni olid eestlaste toitumisharjumused olnud võrdlemisi traditsioonikesksed - perenaised valmistasid toite nii, nagu emadelt ja vanaemadelt õpitud -, siis nüüd muutus menüü rafineeritumaks. Oma osa mängis siin ka suurpere rolli järkjärguline taandumine tuumpere ees: viimases ei valmista toitu enam vana-, vaid noorperenaine, st traditsioone säilitav "vanaemaefekt", omamoodi puhvrina toimiv fenomen, mis takistab innovatsioonide kasutuselevõttu, enam hästi ei toiminud. Täiesti uue nähtusena tulid köögi- ja majapidamiskursused, mida korraldati nii linnades kui maal. Innovatsioonidele mõjus soodsalt ka kujunev toiduaineteadus. Näiteks seente puhul avastati neis sisalduvad toitained, eelkõige valgud. Peagi selgus aga, et seentes sisalduvad valgud on raskesti seeditavad, mistõttu seente toiteväärtus on madal. See info jõudis õige varakult ka eesti lugejani, ${ }^{92}$ mis aitas ilmselt kaasa sellele, et seente võrdlemine lihaga hakkas trükistes vähenema. Samas tugevnes seente koht delikatesside ning maitseainete hulgas.

\section{SLAAVI MÕJUD NING EESKUJUD TOITUMISTRENDI KUJUNDAJANA}

Seente populaarsuse geograafiast rääkides rõhutasime seente rolli slaavi rahvastel. Lisaks seente olulisusele slaavlaste leksikas, sümboolikas, folklooris või ka mentaalsuses tervikuna on seentel nende rahvaste juures oluline roll ka toidumajanduses. Metsaandide korjamise kohta venelastel annavad tunnistust mitmed varased allikad. On teada, et juba 11.-12. sajandil koguti Venemaal metsamarju nende raviomaduste tõttu suurtes kogustes ka talveks. Kiievivene köögis peeti seentest lugu, neid säilitati kuivatatult, soolatult ning hapendatult. ${ }^{93}$ Sajandeid on seened olnud oluline toit poolakatel. ${ }^{94}$

Seente söömist ka Kesk-Euroopa vaesema elanikkonna seas võib pidada slaavi kultuuri mõjuks. Näiteks on Ida- ja Lääne-Preisimaal seeni hoopis rohkem söödud kui muudel Saksa aladel. ${ }^{95}$ Nagu eespool nägime, võib sama tendentsi, et etnilistel kontaktaladel slaavlaste naabruses süüakse seeni rohkem kui muudes maa piirkondades, märgata ka Eestis, aga samuti Soomes. Siinkohal tahaks aga peatuda idapoolsetel eeskujudel ning mõjudel eestikeelses kirjasõnas. Kui LääneEuroopa mõjudest oleme seni mitmel puhul rääkinud seoses uute toitumistrendidega, siis idapoolsed hoovused on tajutavad vähem jõulistena, kuid need on siiski olulised. Esmajärjekorras tuleb siin nimetada tekste, milles kas sedastavalt või propagandistlikel eesmärkidel võrreldakse eestlaste ja venelaste seenetarbimist.

92 Nt Hoffmann, A. Keetmise õpetus. Tartu, 1912, 188.

93 Sergejev, V., Vseviov, D. Venemaa: lähedane ja kauge. Aegade algusest kuni Vassili III-ni. Tallinn, 2002, 166.

94 Staszczak, Z. Einige slavische Gemeinsamkeiten in der traditionellen Volkskultur Schlesiens anhand der Angaben des "Atlas der deutschen Volkskunde". - Ethnologia Slavica nr 4, 1972, 54.

95 Tolksdorf, U. Sammelnahrung in Ost- und Westpreussen. - Jahrbuch für ostdeutsche Volkskunde. Bd 16, 1973, 29. 
A. W. Hupel kõrvutab ühelt poolt eestlasi ja lätlasi ning teiselt poolt venelasi ning rõhutab venelaste suuremat seenelembust. ${ }^{96}$ See on esimene tekst, milles neid kultuure selles seoses üksteisele vastandatakse ning mis juhatab sisse pikaajalise, meie päevini ulatuva traditsiooni. Eriti sageli kohtame sellekohaseid võrdlusi 19. sajandi lõpu ning 20. sajandi alguse tekstides. 1883. aastal tutvustab Mai Reiwelt oma kokaraamatus mitmeid seeneroogi ilmselgelt venekeelsete allikate abil. ${ }^{97}$ 1902. aastal õpetab K. Ruut seeni marineerima ja konserveerima ning viitab mitmes seoses Venemaa vastavatele eeskujudele. ${ }^{98}$

A. Hoffmanni "Keetmise õpetus" (1912) pakub üle 20 seeneroa retsepti - see oli tollal üks esimesi nii ulatuslikke valikuid. Silmatorkav on see, et suur hulk seeneretseptidest pärineb venekeelsest kirjandusest.

Ka nõukogudeaegsed Eestis avaldatud kokaraamatud laenavad seeneretseptid suuresti Venemaal avaldatud kirjandusest, sh mitte ainult kaasaegsetest, vaid ka vanadest 20. sajandi alguse vene kokaraamatutest. ${ }^{99}$ Salme Masso, meie viimaste kümnendite ehk teenekaim kokaraamatute autor, esitab oma 1972. aasta kogumikus kokku üle 200 seeneroa retsepti, mille seas on silmatorkavalt palju selgelt vene algupära toite. Näiteks borš seente ja mustade ploomidega, rassolnik kuivatatud seentega, seentega täidetud tomatid või seenevinegrett esinevad ka paarkümmend aastat varem Moskvas ilmunud venekeelses kokaraamatus. ${ }^{100}$

\section{SEENTE POSITSIOON TÄNASES TOIDUKULTUURIS}

Tendentsid seente tarbimises, mis said alguse 20. sajandi hakul, kui seened asetusid ümber tervislike või dieettoitude rubriiki, on jäänud püsima tänaseni. Seeni tutvustavad trükised rõhutavad nende tervislikkust. Varasemaga võrreldes on hakatud rohkem toonitama seente vitamiinisisaldust (vitamiinid $\mathrm{B}_{1}, \mathrm{C}$ ja $\mathrm{K}$ ) ning rasva- ja kalorivähesust. ${ }^{101}$ Korpulentsus kui gurmaane kimbutav oht vajab tõkestamist ning nii on trendikate toitujate menüüs esikohal kalorivaesed toidud. 1960. aastatest alates on traditsioonilised rammusad ja rasked söögid hakanud asenduma "uue köögiga", mis on rafineeritum ning tervislikum. ${ }^{102}$ Üha enam sekkub toitumise kujundamisse ka meditsiin. Maailmas on tervislik toitumine moeasjaks saanud. Sellega tegelevad ja seda propageerivad arstid arvavad, et tervislike toiduainetega saab asendada pärisravimeid. Mitmes riigis on haiguste riski vähen-

Gorškov, A. V., Maslov, L. A. Bljuda iz gribov. Moskva, 1954.

Nt Hudler, G. W. Magical Mushrooms, Mischievous Molds. New Yersey, 1998, 168; Casimir, M. J. Flocks and Food. A Biocultural Approach to the Study of Pastoral Foodways. Kölner Ethnologische Mitteilungen (koost Ulla Johansen ja Thomas Schweizer). Band 10. Köln, Weimar, 1991, 182.

102 Minaudier, J.-P. Milles seisneb rahva mälu? - Vikerkaar nr 10-11, 2003, 95.
} 
damiseks toiduainetel oma pakendimärgistus, et tervislikud tooted ära tunda, st tegemist ei ole spontaanselt kujunevate moe- ja maitse-eelistustega, vaid teadlikult reguleeritud valikutega, mida suunavad spetsialistide soovitused. Oma koht neis arengutes on ka seenetoitudel. Seente tähtsusele kaasaegses toitumisstrateegias viitab ka seeneroogade valik kokaraamatutes. Tänapäevaste seeneretseptide puhul on rõhk nihkunud põhiroogadelt eelroogadele ja salatitele. Näiteks Kaarina Kaurinkoski mõne aja eest eesti keelde tõlgitud raamatus "Seenetoidud" on ära toodud üle saja seeneroa retsepti, millest näiteks seenesuppe on vaid kuus nimetust. Kõige arvukamalt on esindatud seentest eelroad. ${ }^{103}$

Tänapäevastes koduajakirjades ning kokaraamatutes avaldatavate seeneretseptide puhul torkab silma nende rahvusvahelisus - nõuanded uute toitude alal ületavad riigi- ning keelepiire ilma tõketeta. Tavalised on kõikvõimalikud prantsus-, itaalia- või hiinapärased road, st rõhk on asetatud eksootikale. Ning peamiselt pole neis retseptides kasutatavad seened ei kodumaised riisikad ega puravikud, vaid enamasti konserveeritud või külmutatud šampinjonid. Sageli esinevad seened (loe: šampinjonid) üksikkomponendina roogades, nagu marengo broiler, grillitud paprikasalat, hiinapärane spargelkapsaroog, hakkliha-pajatoit vms ${ }^{104}$ ning loomulikult sellises roas nagu šampinjonisalat. ${ }^{105}$ Kui seente liiki ei määratleta, nt 200 g seeni $^{106}$, leiavad ka siis kasutamist peamiselt võõrsilt imporditud šampinjonid. Samas, kui sügiskuudel avaldatakse spetsiaalselt seenetoitude retsepte näiteks pealkirja all "Seenehorrgutised"107, on enamasti tegemist kodumaiste metsaseentega. Kuid isegi siis on materjal suuresti pärit võõramaistest allikaist. Näiteks seeneroog prantsuse moodi sisaldab kodumaiseid lambatatikaid. ${ }^{108}$ Selles kõiges kajastub veel 19. sajandi trende: spetsiaalsed seeneroad olgu kodumaistest seentest, seeni vaid lisandina kasutavad retseptid sisaldavad aga võõrapäraseid šampinjone.

\section{KOKKUVÕTE}

Käesolevas artiklis nägime, et seente toiduks tarvitamisel on kaks peamist mustrit: ühelt poolt on olnud tegemist vaesema rahva "näljatoiduga", teisele poole jäävas toitumiskäitumises on märksõnadeks tervislik, eksootiline, gurmaanlus. Viimase saja aasta jooksul on piirid nende kahe suuna vahel üha sulanud. 20. sajand vapustas Eestit kahe suure sõjaga. Toiduainete nappus, mis sõdade ajal tavaline, kummitas neil perioodidel ka Eestit. Kui ajakirjandus propageeris näljaaegadel seeni ja seenekorjamist, siis otseselt ajendas seda küll toiduainete nappus, kuid tõhusat tuge propagandale pakkus ka imago, mida seentele oli eelnenud aastakümnetel omistatud - seened kui tervislik toit.

\footnotetext{
103 Kaurinkoski, K. Seenetoidud. Tallinn, 1994.

104 Nt Kodukiri nr 1, 1995, 28, 34; nr 12, 1998, 50.

105 Kodukiri nr 12, 1998, 57.

106 Kodukiri nr 8, 1998, 67.

107 Kodukiri nr 9, 1996, 42.

108 Kodukiri nr 9, 1997, 47.
} 
Näljaaegadest rääkides võib selles seoses meenutada ka Nõukogude Liidu kokkuvarisemisega kaasnenud majanduslikku allakäiku. Langes elanike ostujõud, mis paistis kindlasti välja ka toidulaualt. Metsasaaduste kasutamine oli ka sel ajal vähem kindlustatud elanikkonnale üheks võimaluseks oma toidulauda rikastada. See oli üldine kogu endise Nõukogude Liidu territooriumil - vastavaid näiteid on ilmunud ka teaduskirjanduses. ${ }^{109}$ Samas sellist intensiivset seenepropagandat nagu 20. sajandi eelmistel kriisiperioodidel on ajakirjanduses tehtud, nüüd enam polnud. Õigemini - propaganda pole kuhugi kadunud, kuid nüüd on see reeglipärane seente tutvustamine ajakirjanduses, mis leiab aset igal sügisel, sõltumata majanduslikust hetkeseisust või sellest, kas üks või teine aasta on seenekasvule soodus või mitte. Üks, mida sellest järeldada võime, on see, et seened on omandanud meie toidusedelis mitte just väga olulise, kuid siiski kindla koha.

109 Vt nt Rethmann, P. Tundra Passages. History and Gender in the Russian Far East. Pennsylvania, 2000, XV.

\section{MUSHROOMS IN OUR FOOD}

\section{Attitude Toward Eating Mushrooms and Its Dynamics}

\section{Aivar JÜRGENSON}

The article shows that there have been two main patterns in using mushrooms in food during the last couple of centuries: on the one hand mushrooms have helped poor people during famines, on the other hand terms like healthy, exotic, $\ldots$ have been used to describe mushrooms in food terminology. During the last 100 years the line between these two patterns has diminished. The 20th century shook Estonia with two great wars. Shortage of food is usual during wars, and also in Estonia many people suffered from hunger during the war periods. The propaganda for mushrooms and mushrooming in journalism was directly induced by the lack of food but the propaganda was effectively supported also by the image that mushrooms had acquired before - mushrooms as healthy food.

The economic crisis after the collapse of the Soviet Union weekened also the nation's purchasing power and it was reflected in the food consumption. Mushrooms gave poor people an opportunity to enrich their diets. This was common in the whole territory of the former Soviet Union. However, then journalism did not propagandize mushrooms as widely as during the earlier periods of crisis. It would be correct to say - propaganda has not disappeared but now regular introduction of mushrooms takes place in journalism every autumn despite the economic situation or the amount of mushrooms in the woods. In our food mushrooms have acquired a not very important but a secure position. 